\title{
Investment priorities for the management of hydraulic structures
}

Francesc Pardo-Bosch \& Antonio Aguado

Departament d'Enginyeria de la Construcció, Universitat Politecnica de CatalunyaBarcelona Tech, Barcelona, Spain

C/ Jordi Girona Salgado, 1-3, 08034 Barcelona, Spain.

E-mail: francesc.pardo@upc.edu

antonio.aguado@upc.edu 


\section{Investment priorities for the management of hydraulic structures}

Maintenance management of the hydraulic structures requires the selection of the most necessary maintenance intervention to ensure their proper operation and structural safety. Given the characteristics of these structures, many types of damage may appear, so it is not easy to take a decision. The purpose of this paper is to present the Prioritization Index for the Management of Hydraulic Structures (PIMHS), a multi-criteria decision-making system based on the three axioms of sustainability (social, environmental and economic), which orders and prioritizes non-similar maintenance investments in hydraulic structures. The results obtained show that PIMHS can be used by decision-makers to prioritize, in hydraulic structures, all kind of maintenance interventions where the damages cannot lead to dam break.

Keywords: decision making; sustainability; hydraulic structures; dams; Infrastructure management;

\section{Introduction}

The design, the construction and, above all, the operation of dams together with their supplementary works are justified by the importance that is attached to compensating uneven levels in the water supply that can occur in different areas of the same country. This infrastructure has created a vast engineering heritage throughout the world. According to the International Commission on Large Dams (ICOLD, 2011), 37,640 large dams have been constructed, $40 \%$ of which have been in existence for over 40 years. The ageing of the dams and their functional exploitation means that these civil infrastructures present signs of progressive degradation caused by various types of damage that require interventions for their maintenance and conservation, the objectives of which are either to re-establish or to improve functional, mechanical and safety aspects of the dam itself and/or its immediate surroundings.

Normally, the managers of each dam consider that damage to the structures under their responsibility is the most important and the most urgent to correct. Due to the high cost of maintenance operation, and the limited budget, it is virtually impossible to perform and complete all the required maintenance interventions. Thus, it is important to develop a decision support system that ranks, prioritizes and select the required maintenance interventions. In the field of hydraulic engineering, the nonexistence of a referential framework to assist decision making has meant poor optimization in the selection of maintenance actions (in terms of economic investment and the reduction of risk levels). 
One of the most widely used systems to assist with decision making in civil engineering is Multi-Criteria Decision-Making (MCDM). These systems value each alternative, in a systematic way, in terms of different factors that quantify the benefits and damage that effect the stakeholders, allowing the decision maker to order the alternatives (Tesfamariam \& Sadiq, 2006; Sadiq \& Tesfamariam, 2009 and Huang, Keisler \& Linkov, 2011).

MCDM have been implemented in different areas of decision making and at different levels. In the management of functional infrastructures, for example, they have been used to select maintenance actions for railway systems ferroviarios (Nystr \& Sderholm, 2008), roads (Khadem \& Sheikholeslami, 2010) and bridges (Valenzuela, Solminihac \& Echaveguren 2010). They have also been used to select the key infrastructural projects for the future development of certain regions and countries, as may be seen in Ziara Nigim, Enshassi and Ayyub (2002), Shen, Wu and Zhang (2011), Lambert et al. (2012) or Mejia-Giraldo et al. (2012), among others; and even to select the most appropriate construction alternative from a finite number of possibilities, as may be seen in Shang, Tjader and Ding (2004), Abrishamchi, Ebrahimian, Tajrishi and Mariño (2005), Comisión Permanente del Hormigón (2008), Koo and Ariaratnam (2008) or Ariaratnam, Piratla, Cohen and Olson (2013). Among these multi-criteria systems, we find MIVES (Integrated Model to Qualify Sustainability) (San-Jose \& Garrucho, 2010; Aguado, del Caño, de la Cruz, Gómez \& Josa, 2012; Pons \& Aguado, 2012; and Pons \& Fuente, 2013), a method that is basically used to evaluate various design alternatives presented as solutions to the set problem, comparing at all times similar solutions that present very similar characteristics.

The aim of this paper is to present the Prioritization Index for the Management of Hydraulic Structures (PIMHS), a multi-criteria decision-making system based on MIVES, which orders and prioritizes non-similar maintenance investments in hydraulic structures, providing the deteriorations cannot lead to dam break. The final and most important objective are that $n$ maintenance and conservation actions, which have no common characteristics, may be compared, in order to select those that present a better global response, and that therefore contribute greater added value for both the company and for society.

\section{Decision-making in the field of hydraulic structures}

\subsection{Stochastic or deterministic approach}

The majority of maintenance interventions that are programmed for hydraulic structures aim to correct an existing problem, so that the construction is free from any condition that might lead to its degradation or destruction, with the aim of guaranteeing structural safety.

Large number of research that concerns safety as a topic focused on risk analysis (Hennig, Dise \& Muller, 1997; Bowles, 2001; Scott, 2011; Altarejos-García, Escuder- 
Bueno, Serrano-Lombillo, Gómez de Membrillera-Ortuño 2012; and SPANCOLD, 2013). Risk is defined, according to ICOLD (2005), as a measure of the probability and the severity of the adverse effects of an event on life, health and public and private property, and the environment. The practical proposal of risk analysis may be done by following either a stochastic or a deterministic approach.

The stochastic approach of risk analysis, in all of its theoretical variants, applies very similar calculations, even when they present particular nuances that appear as a hallmark of whoever developed them. As an example, equation 1 (Cyganiewicz \& Smart, 2000), used by the US Bureau of Reclamation, is the standard expression in this field.

$$
\text { Risk }=\mathrm{P}(\text { load }) * \mathrm{P}(\text { adverse response } / \text { load }) * \text { Consequences }
$$

It combines a series of negative consequences in the immediate surroundings with two types of probabilities: the probability that a load will arise, $\mathrm{P}(\mathrm{load})$, and the conditioned probability of adverse response (dam failure) given a certain load.

This type of approach, however, is not adapted to the current needs of dam management. Its constraint is that all risk calculations will be associated with events or loads that cause breaking or failure of the dam ICOLD (2005), even when there is a very low probability of that actually happening (Alonso \& Zaragoza, 2001).

ICOLD (2005) itself also acknowledges that this type of assessment is no easy task, above all for experts that need and look for simple and purely quantitative methods. It therefore even recommends an approach in a more subjective setting such as value analysis or assessment.

Aware of the conceptual and procedural complexity of these calculations, the USBR \& USACE (2012) has affirmed that it is possible to convert the stochastic approach into a deterministic approach, using qualitative or semi-quantitative methods, when a rapid evaluation of a series of cases is needed to decide which risk reduction measures to prioritize over others. Thus, these institutions obtain risk severity through equation 2, converting the stochastic approach into a deterministic approach, thereby obtaining a qualitative result.

$$
\text { Risk }=\mathrm{P}(\text { failure }) * \text { Consequences }
$$

In this equation, $\mathrm{P}$ (response) may be low, moderate, high or very high; and the Consequences can be Level 1 (minimum), Level 2, Level 3 and Level 4 (maximum).

\subsection{Scope of the Decision}

Before defining the decision model, the set of subjects (alternatives) that figure within it should be defined. In this way, the scope of the study has an a priori limitation. In the context of dams, all analyses of these characteristics should take into 
consideration the fact that the scope of the study is configured by all the structural units that constitute the dam: the body of the dam, the abutments, the foundation, the reservoir and ancillary and appurtenant structures.

These structural units are quite clearly different from others, so the damage that they sustain will also, in each case, be of a different nature. In figure 1, a total of 6 different damage modes may be seen: a) cracking around the gates, b) cracks on the teeth at the base of the dam, c) filtrations in galleries, d) ageing of the downstream face of the dam, e) residual movements, and f) small landslide. Taking into account that the decision is unique, as the budgetary heading makes no distinction between one structural unit or another, damage to all units, however different it may be, should be compared, to establish which measures should be considered priority actions.

[Figure 1 near here]

With regard to the interventions on these structural units, it should be pointed out that this study only considers maintenance and conservation works within the standard lifecycle of the dam, which are intended to guarantee that the structure operates in total safety. These interventions are: preventive (among which figure $\mathrm{R}+\mathrm{D}+\mathrm{i}$ studies), rehabilitation, repairs, reinforcement and replacement works.

\section{MIVES method}

MIVES is a decision support system designed for the construction of industrial premises. Its objective is to perform an integrated evaluation of all aspects that affect sustainable development (San-Jose \& Garrucho, 2010; Aguado, del Caño, de la Cruz, Gómez \& Josa, 2012; Pons \& Aguado, 2012; and Pons \& Fuente, 2013). Its great contribution is that it combines Multicriteria Decision Making (MCDM) and MultiAttribute Utility Theory (MAUT), thereby incorporating the value function concept.

The configuration of the decision model is divided in 5 phases: 1) identification of a problem and the precise definition of the decision that has to be taken. 2) Development of the decision tree, a diagram (figure 2) that organizes and structures the concepts that will be evaluated (indicators). The classification is made through the criteria and requirements. 3) Definining of the relative weight of each of aspects that are to be taken into account in the decisión tree (requirements, criteria and indicators). 4) Establishing, for each indicator, a value function that in each case reflects the appraisal of the decision maker. 5) Evaluation, for each alternative, all of indicators and, finally, calculating de sustainability index. The arrows in figure 2 indicate the order of calculation.

\section{[Figure 2 near here]}

The value function (Alarcón et al. 2011) is a single mathematical function that converts the qualitative and quantitative variables of the indicators, with their different units and scales, into a single scale from 0 to 1 . These respective values represent the 
minimum and the maximum degree of satisfaction of the decision maker. In MIVES this value function (equations 3 for growing functions) depends on 5 parameters, the variations of which generate all types of functions: concave, convex, lineal, or in an $\mathrm{S}$ shape, according to the decisions that are taken. The parameters that define the function type are: $\mathrm{Ki}, \mathrm{Ci}, \mathrm{X}$ max., $\mathrm{X}$ min. and $\mathrm{Pi}$. The value of $\mathrm{B}$ that appears in equation 3 is calculated on the basis of the 5 earlier values (equation 4 ).

$$
\mathrm{IV}_{\mathrm{i}}=\mathrm{B}_{\mathrm{i}} *\left[1-\mathrm{e}^{-\mathrm{Ki} *\left(\frac{\mid \mathrm{x}-\mathrm{x}_{\text {min }_{\mathrm{i}} \mid}}{\mathrm{C}_{\mathrm{i}}}\right)^{\mathrm{P}_{\mathrm{i}}}}\right]
$$

where: $X_{\min }$ is the minimum $\mathrm{x}$-axis of the space within which the interventions take place for the indicator under evaluation.

$\mathrm{X}$ is the quantification of the indicator under evaluation (different or otherwise, for each intervention).

$\mathrm{P}_{\mathrm{i}} \quad$ is a form factor that defines whether the curve is concave, convex, linear or an "S" shape: concave curves are obtained for values of $\mathrm{Pi}<1$, convex and "S" shaped forms for $\mathrm{Pi}>1$ and almost straight lines for values of $\mathrm{Pi}=1$. In addition, $\mathrm{Pi}$ gives an approximation of the slope of the curve at the inflection point.

$\mathrm{C}_{\mathrm{i}}$ approximates the $\mathrm{x}$-axis of the inflection point.

$\mathrm{K}_{\mathrm{i}}$ approximates the ordinate of the inflection point.

$\mathrm{B}_{\mathrm{i}}$ is the factor that allows the function to be maintained in the value range of 0 to 1 . This factor is defined by equation 4 .

$$
\mathrm{B}_{\mathrm{i}}=\left[1-\mathrm{e}^{-\mathrm{Ki} *\left(\frac{\left|\mathrm{x}_{\mathrm{max}_{\mathrm{i}}}-\mathrm{x}_{\text {min }_{\mathrm{i}} \mid}\right|}{\mathrm{C}_{\mathrm{i}}}\right)^{\mathrm{P}_{\mathrm{i}}}}\right]^{-1}
$$

where: $\mathrm{X}_{\max }$ is the $\mathrm{x}$-axis of the indicator that generates a value equal to 1 (in the case of functions with increasing values).

Alternatively, functions with decreasing values may be used: i.e. they adopt the maximum value at $X_{\min }$. The only difference in the value function is that the variable $\mathrm{X}_{\min }$ is replaced by the variable $\mathrm{X}_{\max }$, adapting the corresponding mathematical expression.

\section{Decision model}

As discussed in section 2.2, the problems that different structural typologies can present are very diverse and, in consequence, so are the interventions proposed to solve 
them. Faced with the need to compare realities of a multiple nature, it is first of all necessary to establish a framework for equivalences, in order to take the decision. The evaluation process is therefore divided up into two phases, as may be seen in figure 3: 'Phase 1', equivalences, in which the damage that each of the $n$ proposed interventions will repair is analogously compared and evaluated; and 'Phase 2', in which the consequences that may ensue from each damaged structure are evaluated in the contexts where they arise, and the priority order is established through the Prioritization Index for the Management of Hydraulic Structures (PIMHS).

[Figure 3 near here]

\subsection{Phase 1. Equivalent Evaluation of Damage (StD)}

The damage that the structure presents is one of two determining factors in the decision making. Its relevance, moreover, depends on its consequences (the second determining factor). It is therefore, necessary to quantify the importance of the damage (Phase 1), in order to follow criteria when taking the decision, and to do so with a universal system that is valid for all typologies of damage. The engineering concept of Structural Damage $(S t D)$ is defined for that purpose. This new unit performs a semiquantitative evaluation of the capacity of the structure to guarantee the safety and service requirements specified in its initial design. This innovative system can quantify any mode of damage, as it allows the conceptual equivalence of different categories of damage present in different structural typologies, enabling their comparison from that moment.

$S t D$ is evaluated with four independent and complementary variables which, despite their generic nature, ensure the rigor and the representativeness that an analysis of this type needs. Each of these variables responds to a strategic question (see figure 3 ). A score is assigned to each of the variables (treated as attributes) that can range on a scale of 1-5 points, following the recommendation of Williams (2009). As these are independent variables, the scores given to some should not affect the scores of others. The variables are: Degree of Damage $(D e D)$, Location of Damage $(L o D)$, Extension of Damage $(E x D)$ and Evolution of Damage $(E v D)$.

Degree of Damage (DeD). This variable defines the intrinsic seriousness of the damage. In other words, it assesses the extent to which the physical condition of the structure (or of some of its constituent elements) has been altered once the damage has appeared. This variable considers 5 different scenarios for deterioration to describe the state of conservation in which the structure is found, as shown in table 1 . The 5 attributes under consideration encompass all the states that justify an intervention or further analysis. All states that can cause structural weakness are evaluated; if very serious, it is given a score of 5 points, while if it only presents a poor image of the structure due to surface deterioration, it is valued with 1 point.

[Table 1 near here] 
Location of the Damage ( $L o D)$. This variable defines the relative position in which the damage appears. The importance of one type of damage will vary in accordance with the relevance of the structural member on which it is evident. With the intention of creating a coherent, simple, discriminatory grid, representative at the same time of the extensive and complex set of structures that constitute the dam and its reservoir, all possible locations of damage are divided into only 3 groups: critical (when the failure of a damaged element may lead to serious consequences), principal and secondary (when the failure of a damaged element may not lead to negative effects), respectively assigned 5 points, 3 points and 1 point (see table 1). Intermediate values of 2 and 4 are left out, so as to increase the discriminatory capacity of the categorization.

Extension of the Damage (ExD). This variable defines values for which part or portion of the structure is affected by the damage. It is easy to understand that the larger the size (larger space affected), the worse the situation. Extension can be measured by different physical magnitudes: length, surface, volume... In order to compare the magnitude of the damage, each measure is relativized and the evaluation is expressed as a percentage of the total value of the structure affected by the damage. The assignation of scores is done in accordance with the intervals established in table 1.

Temporal Evolution of the Damage $(E v D)$. This variable defines the potential capacity of the pathological process to increase damage to the structure, in the immediate future. A greater possibility of worsening damage will imply greater risk, and therefore a higher score will be allocated to this variable. The physical processes by which damage manifests itself follow a series of sequences that are ordered in time through three temporal phases: the initial or active phase, latent damage or its stabilization, and the inactive or final phase (see table 1). The first arises in any process, although the latter two can arise in the order in which they are presented or one might arise without any need for the other to appear.

Quantification of the final value of the $S t D$ is arrived at through a summary of the four variables (equation 5), in which the variables are weighted according to their relative importance.

$$
\operatorname{StD}\left(A_{x}\right)=\alpha \cdot \operatorname{DeD}\left(A_{x}\right)+\beta \cdot \operatorname{LoD}\left(A_{x}\right)+v \cdot \operatorname{EvD}\left(A_{x}\right)+\mu \cdot \operatorname{ExD}\left(A_{x}\right)
$$

where: $S t D(\mathrm{Ax})$ is the structural damage that would be resolved by intervention $\mathrm{x}(\mathrm{Ax})$

$\alpha, \beta, v, \mu$ are coefficients that represent the weight of each variable, such that their total equals 1 .

The Analytic Hierarchy Process (AHP) (Saaty 1980) is applied, within a committee of experts, in order to determine the value of the coefficients that are attached to the variables. The process is divided into the following steps: construction of the comparison matrix, verification of the consistency of judgments, and calculation of 
the weights of the variables, as can be seen in Appendix A. The final expression of StD is presented in equation 6 .

$\operatorname{StD}\left(\mathrm{A}_{\mathrm{x}}\right)=0.35 \cdot \operatorname{DeD}\left(\mathrm{A}_{\mathrm{x}}\right)+0.35 \cdot \operatorname{LoD}\left(\mathrm{A}_{\mathrm{x}}\right)+0.10 \cdot \operatorname{EvD}\left(\mathrm{A}_{\mathrm{x}}\right)+0.20 \cdot \operatorname{ExD}\left(\mathrm{A}_{\mathrm{x}}\right)(6)$

\subsection{Phase 2. Prioritization Index for the Management of Hydraulic Structures}

Phase 2 of the decision model develops the Prioritization Index for the Management of Hydraulic Structures (PIMHS). The index completes a semiquantitative deterministic evaluation of the degree of sustainability associated with a given maintenance intervention that is proposed to repair the damage previously evaluated in Phase 1: the higher the Prioritization Index, the more important the proposed maintenance intervention.

The degree of sustainability depends on the social, environmental and economic consequences that might arise from the damage, according to the characteristics of the structure and its surroundings. This index, therefore, is a function of both the damage and the consequences (equation 7).

$$
\text { PIMHS }=\mathrm{f}(\text { Damage, } \text { Consequences })
$$

By means of a decision tree, see figure 4, the ideas of the decision maker may be ordered, on the basis of three requirements, from which certain criteria arise that are, in turn, the specific concepts that group the indicators or the tangible characteristics that will be evaluated. In this case, the three requirements are the conceptual axioms of sustainability:

- The Social requirement, the purpose of which is to evaluate the effects that the damage might have on people, has the greatest weight in the decision (50\%). The principal mission of the companies that manage hydraulic works is to guarantee the security of the population. The health and wellbeing of the population is above all other considerations. The requirement is divided into two basic criteria to carry out the evaluation: Physical Persons and Effects, each of which is, in turn, divided into two further indicators. These two criteria are chosen because they permit us to evaluate both the harm that might be inflicted upon a person who may suffer because of the damage (Criterion: Physical Persons) as well as the indirect damage that might affect the ordinary activity of people and organizations (Criterion: Effects).

- $\quad$ The Environmental requirement is the one with the least weight in the decision $(15 \%)$. The greatest impact that hydraulic works has on the natural environment is initially due to their construction. Maintenance projects can have a certain impact, but their impact is never comparable to the construction phase. Even so, this requirement is taken into account because of the intention of managers to strengthen care for the natural environment and to raise the environmental awareness of workers. Only Environmental Impact has been considered as a 
criterion for evaluation, which takes into consideration the negative and/or positive consequences that may arise from the presence of damage and the measures that may be taken to rectify it.

- The Economic requirement, assigned an intermediate weight (35\%), is not intended to strengthen those actions that serve to increase the management benefits. It merely seeks to make the maximum return on each Euro that is invested. Nowadays, the continuance of a company may only be guaranteed, if it manages economic resources in a reasonable manner. If these resources were unlimited, it would not be necessary to prioritize maintenance investments and they would all simply be carried out. The requirement breaks down into two criterion to complete the economic study of the project to be carried out: Initial investment (actual intervention to carry out) and Return on investment (potential future impact of the initial investment)

\section{[Figure 4 near here]}

The final value of the PIMHS for each intervention is calculated by an ascendant process of valuing the indicators and the weighting at the sublevels, thereby integrating the relative weighting of the indicators $\left(w i_{i}\right)$, criteria $\left(w c_{i}\right)$ and requirements $\left(w r_{i}\right)$ in an effective way, as shown in the decision tree in figure 2 , and in equation 8 . The weights once again, were obtained by adjusting the values obtained through the Analytic Hierarchy Process (AHP), which is the most widely used method, at an individual level, to develop decision support systems (Kabir, Sadiq \& Tesfamariam, 2013).

$$
\operatorname{PIMHS}\left(\mathrm{A}_{\mathrm{x}}\right)=\sum \mathrm{wr}_{\mathrm{i}} \cdot \mathrm{wc}_{\mathrm{i}} \cdot \mathrm{wi}_{\mathrm{i}} \cdot \mathrm{IV}_{\mathrm{i}}\left(\mathrm{A}_{\mathrm{i}, \mathrm{x}}\right)
$$

where: PIMHS $\left(A_{x}\right)$ is the prioritization index of intervention $x$

$I V_{i}\left(A_{x}\right)$ is the value of the $i^{t h}$ indicator of intervention $x$

$w r_{i}, w c_{i}$ and $w i_{i}$ are the respective weights of the requirement, criterion and the $i^{\text {th }}$ indicator

Thanks to the PIMHS, a number $\mathrm{n}$ of interventions may be evaluated in an unbiased way, awarding a value between 0 (no importance) and 1 (very important) to each one, which prioritizes them in numerical order.

Limited by its scope, this article does not explain the details behind the calculation of the different indicators that constitute the decision tree. Table 2 presents the following for each indicator: the variables used to define the indicator, the reference units of these variables, and the units that are used to quantify them. More details about these variables are presented in Appendix B. According to Keeney \& Raiffa (1993) the set of attributes and variables has the desirable proprieties. This means that the set is 
complete, operational, decomposable, non-redundant, and minimal. The variables also are: discriminate, comprehensive, and measurable.

The reference variables that are attributes or physical magnitudes grouped into intervals are transformed into points (from 1 to 5), in order to facilitate their use. It is therefore necessary to differentiate between the units that appear in the two columns of that table. The reader may find more complete information in Pardo-Bosch (2014), and in any case, an example is developed in section 5 of the calculation of the Annual Unitary Cost (AUC) indicator.

\section{[Table 2 near here]}

The quantification of some of these indicators (followed by an asterisk (*) in the table 2) depends on the $S t D$ parameter, which integrates the two decision-making phases (Phase 1 and Phase 2). On the one hand, the indicators that assess the direct consequences of the damage $\left(\mathrm{I}_{1}, \mathrm{I}_{3}, \mathrm{I}_{4}\right.$ e $\left.\mathrm{I}_{5}\right)$ are calculated, with the aim of taking into account that the worse the damage, the higher the probability of more serious consequences; and on the other hand, indicator $I_{7}$ (Annual Unitary Cost) in order to spread out the cost of the investment, so as not to penalize the prioritization of those interventions that while expensive, repair damage that is considered significant (see section 5).

A variant of the generic function of the MIVES model (equation 3) is proposed for each indicator, in order to calculate the value of the indicator $\left(\mathrm{VI}_{\mathrm{i}}\right)$ in each case, thereby setting equivalences between the different units that they present. Table 3 presents the coefficients that allow us to define the value function of each indicator in figure 4 . The coefficients were chosen by consensus within a group of experts from the hydraulic sector, from both the public and the private sector.

[Table 3 near here]

\section{Calculation of an indicator}

The particular case of Annual Unitary Cost (AUC) is presented, so that the reader may see how the calculation of an indicator is done. AUC serves to analyze the initial investment, relating the cost of the intervention with its useful life and with the damage that it repairs. In other words, it is an indicator that relates Euros (variable), years (variable) and Structural Damage (attribute).

All maintenance interventions on hydraulic structures respond to a need based on a general interest. The best way of evaluating the investment of this type of project, in which there is normally no income, is through a simplified cost-benefit study.

The cost is the annual depreciation calculated on the initial investment during the useful life of the intervention, thereby converting, with equation 9, an incidental 
expense into an annual deferred cost. In this way, the investments made over different periods of time may be compared.

$$
\text { Cost }=\frac{\text { Initial investment }}{\text { Useful life }}=\text { Annual Cost } \quad\left(\frac{€}{\text { year }}\right)
$$

Simply from a cost perspective, the lower the amount of this variable (fewer Euros/year of expenditure) the more acceptable the intervention, because it allows management to save funds for other interventions.

The direct benefit of any intervention is the damage that it repairs, which is an intangible and not an economic benefit. The only way of quantifying this benefit is through the score assigned to $S t D$, in such a way that Benefit $=\mathrm{StD}$

Note that the direct benefit should only be considered and not the indirect benefit. The indirect benefit is taken into account in the other indicators, whether by valuing the possible consequences that are avoided by the intervention, or by valuing the extra contribution that the intervention entails. To do otherwise would be to commit a serious error, by defining a redundant indicator.

The final quantification of the Annual Unitary Cost (AUC) is obtained by completing the Cost-Benefit analysis with the coefficient that is presented in equation 10, in which the Annual Cost (numerator) is relativized with the score for StD (denominator).

$$
\text { AUC }=\frac{\text { Cost }}{\text { Benefit }}=\frac{\text { Annual Cost }}{\text { StD }}=\frac{\text { Initial investment }}{\text { Useful Life } * \text { StD }} \quad\left(\frac{€}{\text { year }}\right)
$$

The great advantage of relating initial investment with useful life and with $S t D$ is the resulting indicator that values the annual profitability of the operation in relative terms. It moreover avoids using an absolute monetary amount of the investment to define the value of the indicator, which would penalize interventions of a higher cost, even though in some cases they might be of greater necessity than others, considered more economical.

The value of the indicator is obtained through the value function in figure 5, which shows the expression that defines it. In the case, for example, that AUC $=10000$, and $\mathrm{VI}_{7}=0.47$. Likewise, if $\mathrm{AUC}=15000$, then $\mathrm{VI}_{7}=0$. 27. These two values are represented in the value function by a broken line and a dotted line, respectively.

[Figure 5 near here]

\section{Case study}

A total of 5 different maintenance and conservation interventions were selected to demonstrate the application of the model presented in this study and with the scope of 
finding the PIMHS of each intervention. The first three interventions were planned on the same dome dam, while the final two were planned on another straight gravity dam. Both structures are categorized in the Spanish normative legislation (Dirección General de Obras Hidráulicas, 1996) as having maximum irrigation flows. The selected interventions were planned to repair:

A1: A Possible landslides of $35 \mathrm{Hm}^{3}$ of loose soil due to instability on a hillside. The landslide could create a wave (moving upstream with a possible rebound effect) that could indirectly affect the body of the dam, in such a way that it would not, in principle, lead to the collapse of the structure, although it could have some consequences downstream.

A2: Filtrations on the downstream face of the dam, located in the construction joints. If there are further filtrations, it may be necessary to lower the reservoir level, which could affect its operational capacity, slight structural damage also being possible due to the influence of sub-pressures.

A3: Possible landslides of rocky material around the dam abutments. In the case of abutment failure, the downstream consequences would be serious and on a large scale.

A4: The concrete galleries and the body of the dam suffer from expansions due to sulphate attacks. The effect of the attack is considered more intense in galleries, therefore regular maintenance is necessary. No associated affects are predicted.

A5: A recent vertical fissure in a section of the earth containment wall on the access road leading to the Central Generating Plant. There is some movement of a section of soil in the extrados of the wall, revealing a crack and considerable soil displacement. There is a risk of possible damage to the installation and, as a consequence, possible disruption of electricity production.

The study began with the Structural Damage (Phase 1) calculation. In table 4, the value of each variable is presented that allows us to find the final value of the StD for each one of the 5 proposed interventions. From this table, it may be seen that 3 of the 5 interventions (A1, A3 and A5) have the purpose of repairing damage of considerable importance, although it is very difficult to evaluate which is the most important, as the result is very similar. In contrast, interventions A2 and A4 are proposed with the intention of repairing damage of less importance.

[Table 4 near here]

Once the $S t D$ is established, the PIMHS or Prioritization Index for the Management of Hydraulic Structures (Phase 2) has to be calculated. This process is shown in Appendix $\mathrm{C}$, where is presented the quantification of the variables and indicators in accordance with the definitions established in table 2 and Appendix B. With these results we can find, for each intervention, the Indicator Values (IV) and the 
final PIMHS value, that are presented in table 5. These results could be slightly modified if more information would have been available. Thanks to the PIMHS, it may easily be seen that the most pressing intervention is A3, which corresponds to repairs around the abutment to which the dam is attached. The range of values is quite high (from 0.73 to 0.18 ), and the difference that exists between each of the consecutive alternatives is notable $(\approx 0.13)$, which means that the tool is able to discriminate between the interventions under study.

[Table 5 near here]

The result is moreover reasonable and coherent. In the opinion of any technical expert, the associated risk of possible landslides around the dam abutments (A3) is greater than the risk of spillage over the crest provoked by a wave caused by a valleyside landslide (A1). The same may be said of the simple filtration mode (A2), or an expansive reaction in one particular area (A4). Evidence of this is that the order is practically identical to that established by technicians from public authorities and private management companies when they drew up their own prioritization.

Expansive reactions, although an important problem, studied in many technical forums, represent chronic damage that must be monitored and studied, but that do not occasion secondary effects at a practical level, hence its considerably lower score on the PIMHS.

\section{Conclusions}

In an ordinary exercise, a manager has to study hundreds of maintenance and conservation interventions, even though only a small number of them may eventually be implemented. Using sustainability as the main thread in this type of decision-making represents a strategic step forward. The organization that uses the Prioritization Index (PIMHS) to decide on the actions that should be selected will transfer added value to the repair of hydraulic installations, by making optimal use of their resources. In addition, it offers transparency to civil society, which without a doubt makes it more attractive.

The great contribution of the PIMHS is that it allows the evaluation of actions that are not easily comparable and that have to be carried out on totally different structural units, which if not assessed in equivalent terms in phase 1 of the decisionmaking process, may not be compared with the same decision tree. This attribute converts the PIMHS into a totally innovative system.

The decision tree that is used allows us to fragment a complex problem into small independent conjugated sequences. In this way, a schematic analysis is generated that is easy to interpret and easily reproduced by any of the technical experts. Its conceptual and operational simplicity (it only uses what it understands), coupled with its short implementation time and robustness (understood as the capacity of the model to provide coherent results) adds the attributes that make it the ideal tool for taking these 
sort of decisions. When the model has been implemented, the results are rapidly obtained, thereby permitting the comparison of numerous interventions.

\section{Acknowledgements}

This work has been developed within the framework of the UPC and EndesaGeneración SA agreements, represented by Fco. José Conesa, and the Project BIA2010-20913-C02-02 of the Ministerio de Ciencia e Innovación, to whom I thank for their support over the years. The first author is grateful for the scholarship FI (AGAUR) of the Generalitat de Catalunya and the support received from the Col-legid'Engiyers de Camins, Canals i Ports de Catalunya.

\section{References}

Abrishamchi, A., Ebrahimian, A., Tajrishi, M., \& Mariño, M. (2005). Case Study: Application of Multicriteria Decision Making to Urban Water Supply. Journal of Water Resources Planning and Management, 131(4), 326-335. Doi: 10.1061/(ASCE)07339496(2005)131:4(326).

Aguado, A., del Caño, A., de la Cruz, M.P., Gómez, D. \& Josa, A. (2012). Sustainability assessment of concrete structures within the Spanish structural concrete code. Journal of Construction Engineering and Management, 138(2), 268-276. Doi: 10.1061/(ASCE)CO.1943-7862.0000419.

Alarcon, B., Aguado, A., Manga, R. \& Josa, A. (2010). A Value Function for Assessing Sustainability: Application to Industrial Buildings. Sustainability, 3(1), 3550. Doi:10.3390/su3010035.

Alonso, M. y Zaragoza G. (2001). Normativa sobre seguridad de Presas [Dam safety regulations]. Especial XX Congreso de Grandes Presas. Revista de Obras Públicas, 3407, 75-83.

Altarejos-García, L.; Escuder-Bueno, I.; Serrano-Lombillo, A. y Gómez de Membrillera-Ortuño, M. (2012). Methodology for estimating the probability of failure by sliding in concrete gravity dams in the context of risk analysis. Structural Safety, 3637 (3), 1-13. Doi:10.1016/j.strusafe.2012.01.001.

Ariaratnam, S., Piratla, K., Cohen, A., and Olson, M. (2013). Quantification of Sustainability Index for Underground Utility Infrastructure Projects. Journal Construction Engineering and Management. Doi: 10.1061/(ASCE)CO.19437862.0000763 .

Bowles, D. (2001). Evaluation and Use of Risk Estimates in Dam Safety Decisionmaking. Risk-Based Decisionmaking in Water Resources IX, 17-32. Doi: 10.1061/40577(306)3. 
Comisión Permanente del Hormigón (2008). Instrucción de hormigón estructural EHE08 [Concrete Structural Instruction - EHE-08]. Ministerio de Fomento, España, 722 p.

Cyganiewicz J. y Smart J. (2000). U.S. Bureau of Reclamation's use of risk analysis and risk assessment in dam safety decision making. XX International Congress of Large Dams, ICOLD, Q-76, The use of risk analysis to support dam safety decisions and management. Beijing. $19 \mathrm{p}$.

Dirección General de Obras Hidráulicas (1996). Reglamento técnico sobre seguridad de presas y embalses: Serie Legislación. [Technical regulation on safety of dams and reservoirs: Legislation Series]. Ministerio de Obras Públicas, Transportes y Medio Ambiente del Gobierno de España, Madrid. 32 p.

Hennig, C.; Dise, K. y Muller, B. (1997). Achieving Public Protection with Dam Safety Risk Assessment Practices. Risk-Based Decision Making in Water Resources VIII, Proceedings of the Eighth Conference, 19-32.

Huang, I.B., Keisler, J., \& Linkov, I. (2011). Multi-criteria decision analysis in environmental sciences: Ten years of applications and trends. Science of the Total Environment, 409(19), 3578-3594. Doi:10.1016/j.scitotenv.2011.06.022.

ICOLD (2005). Risk Assessment in Dam Safety Management: A Reconnaissance of Benefits, Methods and Current Applications. Bulletin 130. 276 p.

ICOLD (2011). The World Register of Dams. Electronic Register. 2nd Update of 4th editions.

Kabir, G.; Sadiq, R. y Tesfamariam, S. (2013). A review of multi-criteria decisionmaking methods for infrastructure management. Structure and Infrastructure Engineering: Maintenance, Management, Life-Cycle Design and Performance. Doi:10.1080/15732479.2013.795978.

Keeney R.L. \& Raiffa H. (1993). Decisions with Multiple Objectives: Preferences and Value Tradeoffs. Cambridge University Press, 569 p. ISBN 0-521-43883-7.

Khadem, N. \& Sheikholeslami, A. (2010). Multicriteria Group Decision-Making Technique for a Low-Class Road Maintenance Program. Journal of Infrastructure Systems, 16 (3), 188-198. Doi: 10.1061/_ASCE_IS.1943-555X.0000023.

Koo, D. y Ariaratnam, S. (2008). Application of a Sustainability Model for Assessing Water Main Replacement Options. Journal Construction Engineering and Management, 134(8), 563-574. Doi: 10.1061 /_ASCE_0733-9364_2008_134:8_563.

Lambert, J., Karvetski, C., Spencer, D., Sotirin, B., Liberi, D., Zaghloul, H., Koogler. (2012). Prioritizing Infrastructure Investments in Afghanistan with Multiagency 
Stakeholders and Deep Uncertainty of Emergent Conditions. Journal of Infrastructure Systems, 18 (2), 155-166. Doi: 10.1061/(ASCE)IS.1943-555X.0000078.

Mejia-Giraldo, D., Villarreal, J., Gu, Y., He, Y., Duan, Z., \& Wang, L. (2012). Sustainability and Resiliency Measures for Long-Term Investment Planning in Integrated Energy and Transportation Infrastructures. Journal Energy Engineering, 138 (2), 87-94. Doi: 10.1061/(ASCE)EY.1943-7897.0000067.

Nystrm, B. \& Sderholm, P. (2010). Selection of maintenance actions using the analytic hierarchy process (AHP): decision-making in railway infrastructure. Structure and Infrastructure Engineering: Maintenance, Management, Life-Cycle Design and Performance, 6 (4), 467-479, DOI: 10.1080/15732470801990209.

Pardo-Bosch, F (2014). Gestión Integral de Presa de Hormigón: del Diagnóstico a la Inversión [Comprehensive management of concrete dams: from diagnosis to investment]. Unpublished Doctoral Thesis, presentation is scheduled for October 2014. Escuela Técnica Superior de Ingenieros de Canales, Caminos y Puertos, Universitat Politècnica de Catalunya, Barcelona.

Pons, O. \& Aguado, A. (2012). Integrated value model for sustainable assessment applied to technologies used to build schools in Catalonia, Spain. Building and environment, 53, 49-58. Doi: 10.1016/j.buildenv.2012.01.007.

Pons, O. \& Fuente, A. (2013). Integrated sustainability assessment method applied to structural concrete columns. Construction \& building materials, 49, 882-893. Doi: 10.1016/j.conbuildmat.2013.09.009.

Saaty, TL. (1980). The Analytic Hierarchy Process. McGraw-Hill, New York. ISBN:007-054371-2.

Sadiq, R., \& Tesfamariam, S. (2009). Environmental decision-making under uncertainty using intuitionistic fuzzy analytic hierarchy process (IF-AHP). Stochastic Environmental Research and Risk Assessment, 23(1), 75-91. Doi 10.1007/s00477-0070197-z.

San José, JT. \& Garrucho, I. (2010). A system approach to the environmental analysis of industrial buildings. Building \& Environment, 45(3), 673-683. Doi:10.1016/j.buildenv.2009.08.012.

Scott, G. (2011). The Practical Application of Risk Assessment to Dam Safety. GeoRisk 2011, 129-168. Doi: 10.1061/41183(418)6.

Shang, J., Tjader, Y. \& Ding Y. (2004). A Unified Framework for Multicriteria Evaluation of Transportation Projects. IEEE Transactions on Engineering Management, 51 (3), 300-313. Doi: 10.1109/TEM.2004.830848. 
Shen, L., Wu, Y., and Zhang, X. (2011). Key Assessment Indicators for the Sustainability of Infrastructure Projects. Journal Construction Engineering and Management, 137(6), 441-451. Doi: 10.1061/(ASCE)CO.1943-7862 .0000315.

SPANCOLD (2013). Risk Analysis Applied to Management of Dam Safety. Technical Guides on Dam Safety: Technical Guide on operation of dams and reservoirs. Madrid, $50 \mathrm{p}$.

Tesfamariam, S., \& Sadiq, R. (2006). Risk-based environmental decision-making using fuzzy analytic hierarchy process (F-AHP). Stochastic Environmental Research\&Risk Assessment, 21(1), pp 35-50. Doi: 10.1007/s00477-006-0042-9.

USBR \& USACE (2012). Chapter 3 - Qualitative and Semi-Quantitative Assessments. Best Practices in Dam and Levee Safety Risk Analysis. (pp. 3-1-3-16). U.S. Department of the Interior, Washington, DC.

Valenzuela S., Solminihac de, H. \& Echaveguren, T. (2010). Proposal of an Integrated Index for Prioritization of Bridge Maintenance. Journal of Bridge Engineering, 15 (3), 337-343. Doi: 10.1061/_ASCE_BE.1943-5592.0000068.

Williams, M. (2009). Introducción a la Gestión de proyectos [The Principles of Project Management]. Anaya, Madrid, 224 p.

Ziara, M., Nigim, K., Enshassi, A., \& Ayyub, B. (2002). Strategic Implementation of Infrastructure Priority Projects: Case Study in Palestine. Journal of Infrastructure Systems, 8(1), 2-11. Doi: 10.1061/(ASCE)1076-0342(2002)8:1(2). 


\section{Appendix A.}

The Analytic Hierarchy Process is divided into de following steps:

Construction of the comparison matrix. The comparison matrix (M) is a matrix that compares the significance of the variables that appear in the first column with de the variables of the column $1+\mathrm{j}$, with $\mathrm{j}>1$. The matrix $\mathrm{M}$, that the expert committee determined, is presented in equation AA1.

$M=$\begin{tabular}{|c|c|c|c|c|}
\cline { 2 - 5 } \multicolumn{1}{c|}{} & DeD & LoD & $E x D$ & $E v D$ \\
\hline DeD & 1 & 1 & 4 & 2 \\
\hline LoD & 1 & 1 & 4 & 2 \\
\hline$E x D$ & $1 / 4$ & $1 / 4$ & 1 & $1 / 2$ \\
\hline$E v D$ & $1 / 2$ & $1 / 2$ & 2 & 1 \\
\hline
\end{tabular}

Experts consider $D e D$ and $L o D$ the most important variables. Consequently, they received bigger weight. The least important variable, according to this method, is the variable $E x D$.

Verification of the consistency of judgments. The relationships between variables are entirely consistent if the comparison matrix $\mathrm{M}$ is a reciprocal matrix of rank 1. These matrices only have different zero eigenvalue. In these cases, the eigenvalue is $\lambda=$ n. In equation AA.2, the reader can see how the eigenvalues are calculated. The result is presented in equation AA3.

$$
\begin{gathered}
|\mathrm{M}-\mathrm{Id} \cdot \lambda|=\left[\begin{array}{cccc}
1-\lambda & 1 & 4 & 2 \\
1 & 1-\lambda & 4 & 2 \\
1 / 4 & 1 / 4 & 1-\lambda & 1 / 2 \\
1 / 2 & 1 / 2 & 2 & 1-\lambda
\end{array}\right]=0 \\
\lambda 1=4 ; \lambda 2=\lambda 3=\lambda 4=0
\end{gathered}
$$

Therefore the relationships are entirely consistent

Calculation the weights of the variables. To calculate the relative weights of each variable we must: a) calculate the normalized matrix $\mathrm{N}$, dividing each element of the $\mathrm{i}$ column of the matrix $\mathrm{M}$ by the sum of the elements of that column (equation AA.4); b) estimate the vector P, calculating the average of each line of the normalized matrix (equation AA.5). 


$$
\begin{gathered}
N=\left[\begin{array}{llll}
0,36 & 0,35 & 0,36 & 0,36 \\
0,36 & 0,35 & 0,36 & 0,36 \\
0,09 & 0,12 & 0,09 & 0,09 \\
0,18 & 0,18 & 0,18 & 0,18
\end{array}\right] \\
P=\left[\begin{array}{c}
\alpha^{\prime} \\
\beta^{\prime} \\
\mu^{\prime} \\
v^{\prime}
\end{array}\right]=\left[\begin{array}{l}
0,36 \\
0,36 \\
0,09 \\
0,18
\end{array}\right] \rightarrow P=\left[\begin{array}{l}
\alpha \\
\beta \\
\mu \\
v
\end{array}\right]=\left[\begin{array}{l}
0,35 \\
0,35 \\
0,10 \\
0,20
\end{array}\right]
\end{gathered}
$$

The final expression of $S t D$ is presented in equation 6 .

Appendix B. Variables that define indicators with their respective scores. (Table Appendix B)

${ }^{1}$ Adaptet from: USACE (1979) \& USBR (1988)

USACE (1979). Recommended Guidelines for the Safety Inspection of Dams. Office of the Chief of Engineers, U.S.,Corps of Engineers, Washington D.C. 33 p.

USBR (1988). Downstream Hazard Classification Guidelines: ACER Technical Memorandum. Bureau of Reclamation, Denver, $\mathrm{n}^{\circ} 11,56 \mathrm{p}$.

${ }^{2}$ Dirección General de Obras Hidraulicas (1997). Clasificación de Presas en Función del Riesgo Potencial: Guía Técnica [Classification of Dams Based on Potential Risk: Technical Guide]. Ministerio de Medio Ambiente del Gobierno de España, Madrid, 64p.

${ }^{3}$ Conesa, F.J., (2010). Procedimiento para la evaluación del estado de seguridad en presas y priorización de actuaciones [Procedure for assessment of the security status in dams and prioritizing actions]. Master's thesis. Barcelonatech. Barcelona.

4 Gómez, D. (1988). Evaluación del impacto ambiental de proyectos agrarios [Environmental impact assessment of agricultural projects]. Ministerio de Agricultura Pesca y Alimentación. Estudios monográficos $n^{\circ}$ 6. Madrid.

5 Arboleda J., (1994). Una propuesta para la identificación y evaluación de impactos ambientales [A proposal for the identification and evaluation of environmental impacts]. Crónica Forestal y del Medio Ambiente, no 9, pp 71-81.

Appendix C. Variables and indicators qualifications . (Table Appendix C) 
Table 1. Variables that define StD with their respective scores

\begin{tabular}{cccccc}
\hline Variable & Attribute & Points & Variable & Attribute & Points \\
\hline \multirow{2}{*}{ Degree of } & Very Serious & 5 & & Total & 5 \\
Damage & Serious & 4 & Extension of & Generalized & 4 \\
$($ DeD $)$ & Slight & 2 & Damage & Medium & 3 \\
& Very Slight & 1 & $($ ExD $)$ & Localized & 2 \\
& & & Incidental & 1 \\
Location of & Critical & 5 & Evolution of & Initial/Active & 5 \\
Damage & Principal & 3 & Damage & Latent & 3 \\
$($ LoD) & Secondary & 1 & (EvD) & Inactive & 1 \\
\hline
\end{tabular}


Table 2. Variables to measure for each indicator

\begin{tabular}{|c|c|c|c|c|}
\hline & \multirow{2}{*}{ Indicator } & \multirow{2}{*}{ Variables to Measure } & \multicolumn{2}{|c|}{ Units } \\
\hline & & & \multicolumn{2}{|c|}{ Reference To evaluate } \\
\hline \multirow[t]{3}{*}{ I } & Population exposed to & Number affected people (NAP) & num. & points \\
\hline & risk* $^{*}(\mathrm{PoE})$ & Typology Spatial Occupation (TSO) & attribute & points \\
\hline & & $\mathrm{PoE}=(0.8 \cdot \mathrm{NAP}+0.2 \cdot \mathrm{TSO}) \cdot \mathrm{STD}$ & & \\
\hline \multirow[t]{3}{*}{$\mathrm{I}_{2}$} & Collective Perception of & Damage Observed by Public (DOP) & attribute & points \\
\hline & the Risk (CPR) & Register of Incidents (ReI) & attribute & points \\
\hline & & $\mathrm{CPR}=\mathrm{DOP}+\mathrm{ReI}$ & & \\
\hline \multirow[t]{3}{*}{$\mathrm{I}_{3}$} & Essential services & Scope Territorial Interruption (STI) & attribute & points \\
\hline & affected* $(\mathrm{ESA})$ & Time Service Interruption (TSI) & hours & points \\
\hline & & $\mathrm{ESA}=(\mathrm{STI} \cdot \mathrm{TSI}) \cdot \mathrm{STD}$ & & \\
\hline \multirow[t]{5}{*}{$\mathrm{I}_{4}$} & Material-economic & $\mathrm{N}^{\circ}$ of Houses (NHo) & number & points \\
\hline & damage* (MED) & $\mathrm{N}^{\mathrm{o}}$ Industries (NIn) & number & points \\
\hline & & Unirrigated (dry) cultivation (UnC) & $\mathrm{hm}^{2}$ & points \\
\hline & & Irrigated cultivation (IrC) & $\mathrm{hm}^{2}$ & points \\
\hline & & $\mathrm{MED}=(\mathrm{Ho}+\mathrm{In}+\mathrm{UC}+\mathrm{IC}) \cdot \mathrm{STD}$ & & \\
\hline \multirow[t]{5}{*}{$\mathrm{I}_{5}$} & Negative Repercussions & Intensity of the Impact (InI) & attribute & points \\
\hline & of the Damage* (NRD) & Extension of the Impact (ExI) & $\%$ & points \\
\hline & & Duration of the Impact (DuI) & years & points \\
\hline & & Typology of the Natural Area (TNA) & attribute & points \\
\hline & & $\mathrm{NRD}=\mathrm{TNA} \cdot(3 \mathrm{InI}+2 \mathrm{ExI}+\mathrm{DuI}) \cdot \mathrm{STD}$ & & \\
\hline \multirow[t]{5}{*}{$\mathrm{I}_{6}$} & Added Value & Intensity of the Impact (InI) & attribute & points \\
\hline & Intervention (AVI) & Extension of the Impact (ExI) & $\%$ & points \\
\hline & & Duration of the Impact (DuI) & years & points \\
\hline & & Typology of the Natural Area (TNA) & attribute & points \\
\hline & & $\mathrm{AVI}=\mathrm{TNA} \cdot(3 \mathrm{InI}+2 \mathrm{ExI}+\mathrm{DuI})$ & & \\
\hline \multirow[t]{3}{*}{$\mathrm{I}$} & Annual Unitary Cost* & Initial Investment (InI) & Euros & euros \\
\hline & $(\mathrm{AUC})$ & Useful Life of Intervention (ULI) & years & years \\
\hline & & $\mathrm{AUC}=\mathrm{InI} /(\mathrm{ULI} \cdot \mathrm{STD})$ & & \\
\hline \multirow[t]{3}{*}{$\mathrm{I}_{8}$} & Savings Maintenance & Supported Annual Expenditure (SAE) & Euros & euros \\
\hline & $(\mathrm{SeM})$ & Predicted Annual Expenditure (PAE) & Euros & euros \\
\hline & & $\mathrm{SeM}=\mathrm{SAE}-\mathrm{PAE}$ & & \\
\hline \multirow[t]{3}{*}{$\mathrm{I}_{9}$} & Increase Estimated & Potential Increase Production (PIP) & GWh & Gwh \\
\hline & Production (IEP) & Limitations of Intervention (LiI) & $\%$ & $\%$ \\
\hline & & IEP $=$ PIP $\cdot$ LiI & & \\
\hline & tom endition d b & & & \\
\hline
\end{tabular}


Table 3. Value function parameters for each criterion

\begin{tabular}{lccccccc}
\hline Indicator & $\mathrm{X}_{\min }$ & $\mathrm{X}_{\max }$ & $\mathrm{P}_{\mathrm{i}}$ & $\mathrm{C}_{\mathrm{i}}$ & $\mathrm{K}_{\mathrm{i}}$ & $\mathrm{B}_{\mathrm{i}}$ & Shape \\
\hline Population Exposed to risk & 1 & 25 & 2 & 7 & 0.6 & 1.0 & $\mathrm{~S}$ \\
Collective Perception of the Risk & 1.5 & 20 & 2 & 5 & 0.25 & 1.0 & $\mathrm{~S}$ \\
Essential Services Affected & 1 & 120 & 1 & 100 & 3.5 & 1.0 & Convex \\
Economic Material Damage & 4 & 100 & 1 & 1 & 0.01 & 10.9 & Straight \\
Negative Impact of the Damage & 6 & 300 & 2 & 80 & 0.5 & 1.0 & $\mathrm{~S}$ \\
Added Value of Intervention & 0 & 60 & 1 & 10 & 0.7 & 1.0 & Convex \\
Annual Unitary Cost & 0 & $3 \cdot 10^{4}$ & 2 & $5 \cdot 10^{4}$ & 0.6 & 5.1 & Concave (d) \\
Saving on Maintenance Supervision & 0 & $6 \cdot 10^{4}$ & 2 & $15 \cdot 10^{4}$ & 1 & 4.5 & Convex \\
Increase in Estimated Production & 0 & 900 & 1 & 600 & 1 & 1.0 & Concave \\
\hline
\end{tabular}

NB: $(d)=$ decreasing

Table 4. Quantification of Structural Damage for each proposed intervention

\begin{tabular}{lccccc}
\cline { 2 - 6 } & A1 & A2 & A3 & A4 & A5 \\
\hline Degree of Damage $(D e D)$ & 5 & 4 & 5 & 3 & 5 \\
\hline Location of Damage $(L o D)$ & 5 & 3 & 5 & 1 & 4 \\
\hline Extension of Damage $(E x D)$ & 2 & 3 & 5 & 4 & 2 \\
\hline Evolution of Damage $(E v D)$ & 5 & 3 & 3 & 3 & 5 \\
\hline Structural Damage $(\boldsymbol{S t D})$ & $\mathbf{4 . 7}$ & $\mathbf{3 . 3 5}$ & $\mathbf{4 . 6}$ & $\mathbf{2 . 4}$ & $\mathbf{4 . 3 5}$ \\
\hline
\end{tabular}

Table 5. Prioritization index (PIMSH) of each proposed intervention

\begin{tabular}{lccccc} 
& \multicolumn{5}{c}{ Indicator Value $\left(\mathrm{IV}_{\mathrm{i}}\right)$} \\
& $\mathrm{A} 1$ & $\mathrm{~A} 2$ & $\mathrm{~A} 3$ & $\mathrm{~A} 4$ & $\mathrm{~A} 5$ \\
\hline $\mathrm{IV}_{\text {PoE }}$ & 0.99 & 0.06 & 0.99 & 0.02 & 0.51 \\
$\mathrm{IV}_{\text {CPR }}$ & 0.48 & 0.79 & 0.48 & 0.25 & 0.70 \\
$\mathrm{IV}_{\text {ESA }}$ & 0.77 & 0.08 & 0.91 & 0.04 & 0.11 \\
$\mathrm{IV}_{\text {MED }}$ & 0.54 & 0.23 & 0.72 & 0.05 & 0.03 \\
$\mathrm{IV}_{\text {NID }}$ & 0.73 & 0.08 & 0.74 & 0 & 0.03 \\
$\mathrm{IV}_{\text {VAA }}$ & 0 & 0.39 & 0.17 & 0 & 0.25 \\
IV $_{\text {AUC }}$ & 0.68 & 0.82 & 0.81 & 0.80 & 0.93 \\
IV $_{\text {MSS }}$ & 0.09 & 0.06 & 0.58 & 0.1 & 0.06 \\
IV $_{\text {EIP }}$ & 0.21 & 0.11 & 0.21 & 0 & 0.75 \\
\hline PIMHS & $\mathbf{0 . 6 0}$ & $\mathbf{0 . 3 0}$ & $\mathbf{0 . 7 3}$ & $\mathbf{0 . 1 8}$ & $\mathbf{0 . 4 5}$ \\
\hline
\end{tabular}


Table Appendix B. Variables that define indicators with their respective scores

\begin{tabular}{|c|c|c|c|c|c|}
\hline Variable & Attributes & Points & Variable & Attributes & Points \\
\hline \multirow{5}{*}{$\begin{array}{c}\text { Number of } \\
\text { affected } \\
\text { people }^{1} \\
\text { (NAP) }\end{array}$} & $n^{\circ}>300$ & 5 & \multirow{5}{*}{$\begin{array}{l}\text { Typology of } \\
\text { Spatial } \\
\text { Occupation } \\
\text { (TSO) }\end{array}$} & Urban areas for live & 5 \\
\hline & $30<\mathrm{n}^{\mathrm{o}} \leq 300$ & 4 & & Dispersed houses & 4 \\
\hline & $6<\mathrm{n}^{\circ} \leq 30$ & 3 & & Permanent (not houses) & 3 \\
\hline & $1<\mathrm{n}^{\circ} \leq 6$ & 2 & & Areas timely occupation & 2 \\
\hline & $\mathrm{n}^{\mathrm{o}} \leq 1$ & 1 & & Unoccupied areas & 1 \\
\hline \multirow{5}{*}{$\begin{array}{l}\text { Damage } \\
\text { Observed by } \\
\text { the Public } \\
\left(\mathrm{DOP}_{\mathrm{i}}\right)\end{array}$} & Breaks & 5 & \multirow{6}{*}{$\begin{array}{c}\text { Register of } \\
\text { Incidents (ReI) }\end{array}$} & In the same structure & 5 \\
\hline & Leaks & 4 & & In neighboring area & 4 \\
\hline & Fissures & 3 & & In the same province & 3 \\
\hline & Blotch - Humidity & 2 & & In the same region & 2 \\
\hline & Movements & 1 & & In the same state & 1 \\
\hline \multicolumn{3}{|c|}{$\mathrm{DOP}=1,5 \cdot \mathrm{DOP}_{1}+1,35 \mathrm{DOP}_{2}+\mathrm{DOP}_{3}$} & & In the same state & 1 \\
\hline \multirow{5}{*}{$\begin{array}{c}\text { Scope of } \\
\text { Territorial } \\
\text { Interruption } \\
\quad \text { (STI) }\end{array}$} & National & 5 & \multirow{5}{*}{$\begin{array}{c}\text { Time } \\
\text { Interruption } \\
\text { Service (TIS) }\end{array}$} & $>2$ days & 5 \\
\hline & Regional & 4 & & $12 \mathrm{~h}<\mathrm{t}<48 \mathrm{~h}$ & 4 \\
\hline & Local & 3 & & $6 \mathrm{~h}<\mathrm{t}<12 \mathrm{~h}$ & 3 \\
\hline & Punctual & 2 & & $1 \mathrm{~h}<\mathrm{t}<6 \mathrm{~h}$ & 2 \\
\hline & No scope & 1 & & $<1 \mathrm{~h}$ & 1 \\
\hline \multirow{3}{*}{$\begin{array}{c}\mathrm{N}^{\circ} \text { of Houses } \\
(\mathrm{NHo})\end{array}$} & $\mathrm{n}^{\circ}>100$ & 5 & \multirow{3}{*}{$\begin{array}{l}\mathrm{N}^{\mathrm{o}} \text { Industries } \\
(\mathrm{NIn})^{3}\end{array}$} & $\mathrm{n}^{\circ}>50$ & 5 \\
\hline & $100>n^{\circ}>10$ & 3 & & $50>n^{\circ}>10$ & 3 \\
\hline & $10>n^{o}$ & 1 & & $10>\mathrm{n}^{\mathrm{o}}$ & 1 \\
\hline Unirrigated & $\mathrm{hm}^{2}>10 \cdot 10^{3}$ & 5 & Irrigated & $\mathrm{hm}^{2}>5 \cdot 10^{3}$ & 5 \\
\hline Cultivation & $5 \cdot 10^{3}<\mathrm{hm}^{2}<10 \cdot 10^{3}$ & 3 & Cultivation & $1 \cdot 10^{3}<\mathrm{hm}^{2}<5 \cdot 10^{3}$ & 3 \\
\hline $\operatorname{Area}^{3}(\mathrm{UnC})$ & $\mathrm{hm}^{2}<5 \cdot 10^{3}$ & 1 & $\operatorname{Area}^{3}(\mathrm{ICA})$ & $\mathrm{hm}^{2}<1 \cdot 10^{3}$ & 1 \\
\hline \multirow{5}{*}{$\begin{array}{l}\text { Intensity of } \\
\text { the Impact } \\
\quad \text { (InI) }\end{array}$} & \multirow{2}{*}{ High } & \multirow[t]{2}{*}{5} & \multirow{5}{*}{$\begin{array}{l}\text { Extension of } \\
\text { the Impact } \\
\qquad(\text { ExI })\end{array}$} & Very High $(>80 \%)$ & 5 \\
\hline & & & & $\operatorname{High}(60<\%<80)$ & 4 \\
\hline & Medium & 3 & & Medium $(40<\%<60)$ & 3 \\
\hline & \multirow{2}{*}{ Low } & \multirow{2}{*}{1} & & Low $(20<\%<40)$ & 2 \\
\hline & & & & Very Low $(<20 \%)$ & 1 \\
\hline \multirow{6}{*}{$\begin{array}{l}\text { Duration of } \\
\text { the Impact } \\
\text { (DuI) }\end{array}$} & $>10$ years & 5 & \multirow{6}{*}{$\begin{array}{l}\text { Typology of } \\
\text { the Natural } \\
\text { Area (TNA) }\end{array}$} & Parks & 2 \\
\hline & $7<$ years $<10$ & 4 & & Nature Reserves & 1.8 \\
\hline & $4<$ years $<7$ & 3 & & Marine special areas & 1.6 \\
\hline & $1<$ years $<4$ & 2 & & Monuments & 1.4 \\
\hline & $<1$ year & 1 & & Protected Landscapes & 1.2 \\
\hline & < 1 year & 1 & & NO protected areas & 1 \\
\hline \multirow{5}{*}{$\begin{array}{l}\text { Potential } \\
\text { Increase } \\
\text { Production } \\
\quad \text { (PIP) }\end{array}$} & \multirow{5}{*}{\multicolumn{2}{|c|}{$\begin{array}{c}\text { PIP=MIP-AcP } \\
\text { Max installed power (MIP) } \\
\text { Actual power (AcP) }\end{array}$}} & \multirow{5}{*}{$\begin{array}{l}\text { Limitations } \\
\text { Intervention } \\
\quad \text { (LiI) }\end{array}$} & Total increase & 1 \\
\hline & & & & Only $75 \%$ increase & 0.75 \\
\hline & & & & Only $50 \%$ increase & 0.5 \\
\hline & & & & Only $25 \%$ increase & 0.25 \\
\hline & & & & Impossible increase & 0 \\
\hline
\end{tabular}

${ }^{1}$ Adaptet from USACE (1979) \& USBR (1988), ${ }^{2}$ Dirección General de Obras Hidráulicas (1997), ${ }^{3}$ Conesa (2010), ${ }^{4}$ Gómez (1988), ${ }^{5}$ Arboleda (1994) 
Table Appendix C. Variables and indicators qualifications

\begin{tabular}{|c|c|c|c|c|c|c|}
\hline \multirow{2}{*}{$\mathrm{I}_{\mathrm{i}}$} & \multirow{2}{*}{ Variable } & \multicolumn{5}{|c|}{ Quantification } \\
\hline & & $\mathrm{A} 1$ & A2 & A3 & A4 & A5 \\
\hline & $\operatorname{NAP}(p)$ & 5 & 1 & 5 & 1 & 2 \\
\hline & TSO (p) & 5 & 1 & 5 & 1 & 2 \\
\hline \multirow[t]{3}{*}{$\mathrm{I}_{1}$} & $\mathrm{PoE}$ & 23.5 & 3.3 & 23 & 2.4 & 8.7 \\
\hline & $\operatorname{DOP}(p)$ & $(3,0,0)$ & $(4,2,0)$ & $(3,0,0)$ & $(3,1,0)$ & $(3,5,0)$ \\
\hline & $\operatorname{ReI}(p)$ & 5 & 5 & 5 & 1 & 1 \\
\hline \multirow[t]{3}{*}{$\mathrm{I}_{2}$} & $\mathrm{CPR}(\mathrm{p})$ & 9.5 & 13.7 & 9.5 & 6.85 & 12.2 \\
\hline & STI (p) & 3 & 1 & 3 & 1 & 1 \\
\hline & TIS (p) & 3 & 1 & 5 & 1 & 1 \\
\hline \multirow[t]{5}{*}{$\mathrm{I}_{3}$} & ESA & 42.3 & 3.3 & 69 & 2.4 & 4.3 \\
\hline & NHo (p) & 3 & 1 & 5 & 1 & 1 \\
\hline & NIn (p) & 3 & 1 & 3 & 1 & 1 \\
\hline & $\mathrm{UCA}(\mathrm{p})$ & 3 & 1 & 5 & 1 & 1 \\
\hline & $\operatorname{ICA}(p)$ & 3 & 5 & 3 & 1 & 1 \\
\hline \multirow[t]{5}{*}{$\mathrm{I}_{4}$} & MED & 56,4 & 26.8 & 73.6 & 9.6 & 17.4 \\
\hline & $\operatorname{InI}(\mathrm{p})$ & 5 & 3 & 5 & 1 & 1 \\
\hline & $\operatorname{ExI}(p)$ & 5 & 1 & 5 & 1 & 1 \\
\hline & $\operatorname{DuI}(\mathrm{p})$ & 4 & 1 & 5 & 1 & 1 \\
\hline & TNA (p) & 1 & 1 & 1 & 1 & 1 \\
\hline \multirow[t]{5}{*}{$\mathrm{I}_{5}$} & NID & 136.3 & 40.2 & 138 & 14.4 & 26.1 \\
\hline & InI (p) & 1 & 3 & 3 & 1 & 1 \\
\hline & $\operatorname{ExI}(p)$ & 1 & 1 & 3 & 1 & 2 \\
\hline & $\operatorname{DuI}(p)$ & 1 & 2 & 2 & 1 & 3 \\
\hline & TNA (p) & 1 & 1 & 1 & 1 & 1 \\
\hline \multirow[t]{3}{*}{$\mathrm{I}_{6}$} & VAA & 6 & 13 & 17 & 6 & 10 \\
\hline & $\operatorname{InI}(€)$ & 400000 & 100000 & 750000 & 80000 & 150000 \\
\hline & ULI (years) & 15 & 10 & 50 & 10 & 30 \\
\hline \multirow[t]{3}{*}{$\mathrm{I}_{7}$} & UAC & 5673.7 & 2985.1 & 3260.8 & 3333.3 & 1149.4 \\
\hline & $\operatorname{SAE}(€)$ & 25000 & 15000 & 75000 & 10000 & 15000 \\
\hline & $\operatorname{PAE}(€)$ & 7500 & 0 & 30000 & 4000 & 0 \\
\hline \multirow[t]{3}{*}{$\mathrm{I}_{8}$} & MSS & 17500 & 15000 & 45000 & 60000 & 15000 \\
\hline & PIP (GW·h) & 31.5 & 31.5 & 31.5 & 187.5 & 186.2 \\
\hline & LiI & 1 & 0.5 & 1 & 0 & 1 \\
\hline $\mathrm{I}_{9}$ & EIP & 31.5 & 15.75 & 31.5 & 0 & 186.2 \\
\hline
\end{tabular}


List of Figures:

\section{Figure 1. Example of different types of damage}
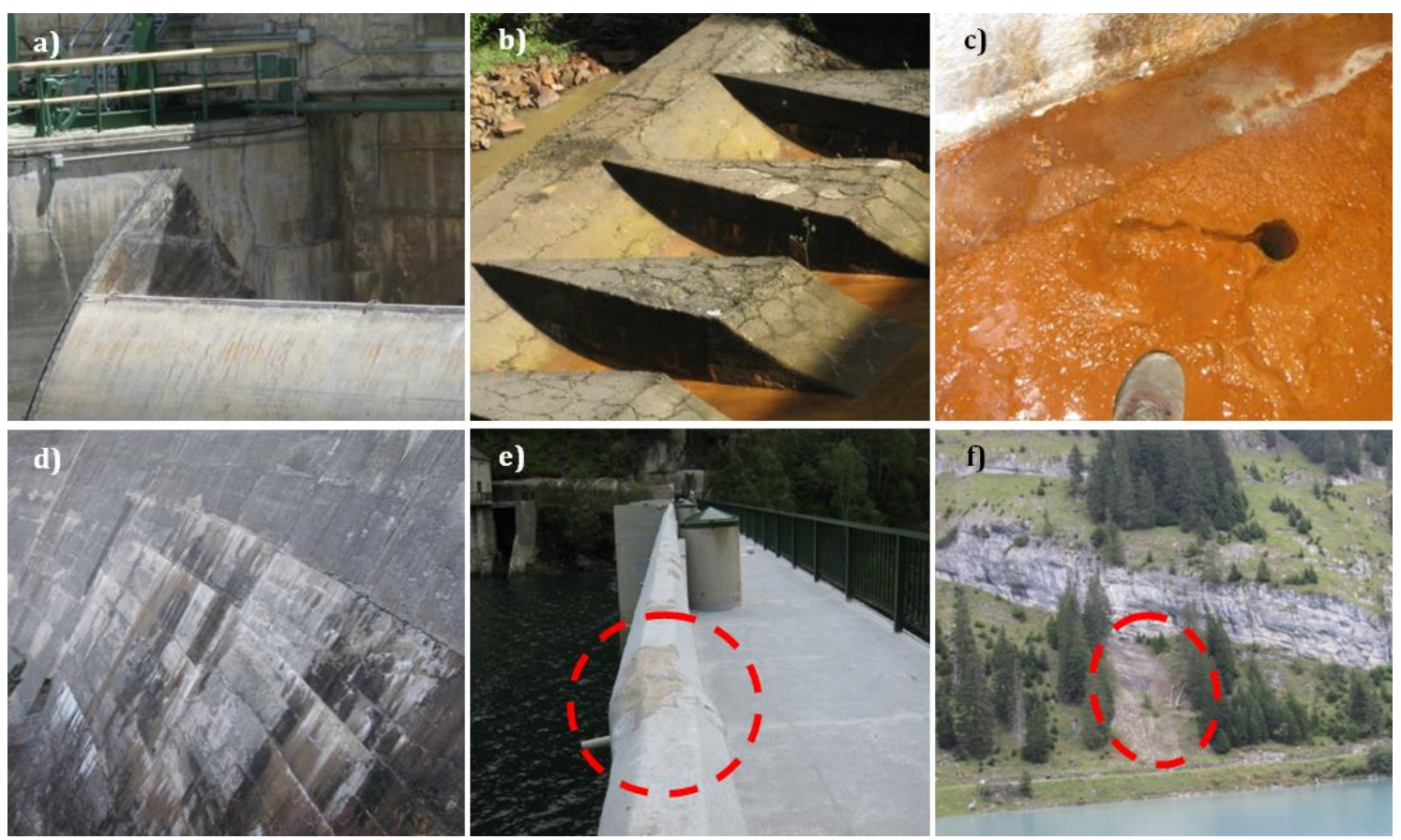

\section{Figure 2. Generic Decision Tree}

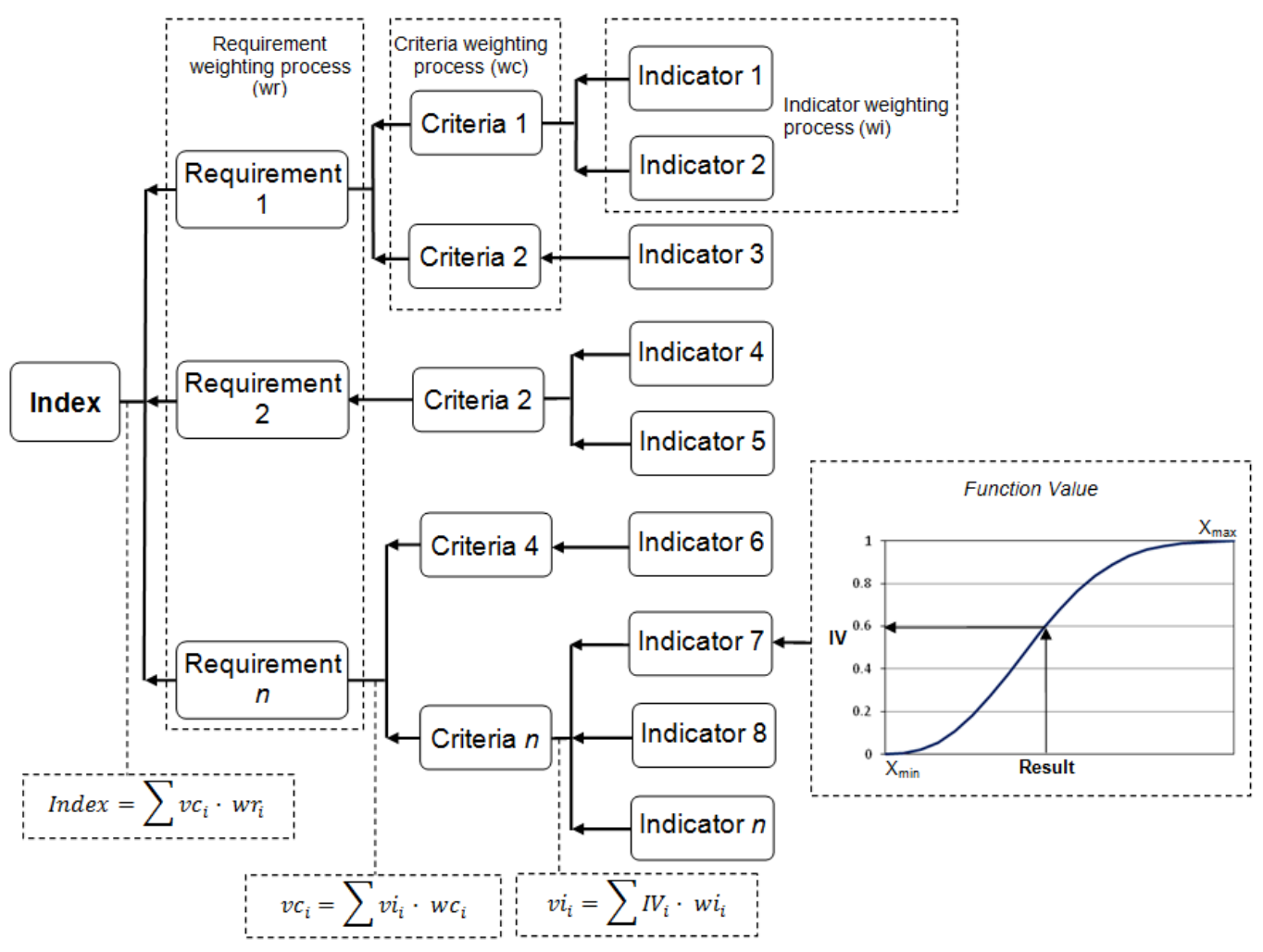


Figure 3. Decision's phases and the variables that define Structural Damage (StD)

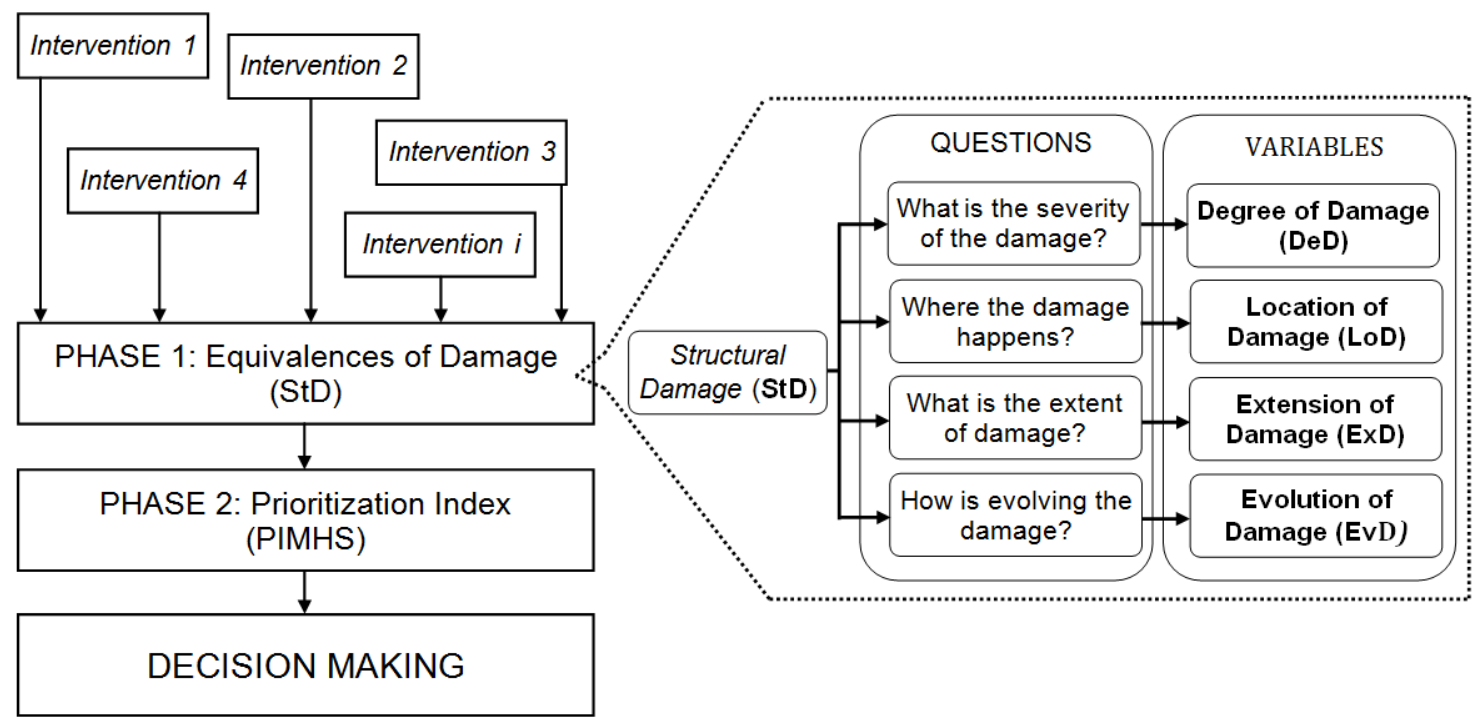

Figure 4. Decision Tree for the PIMSH

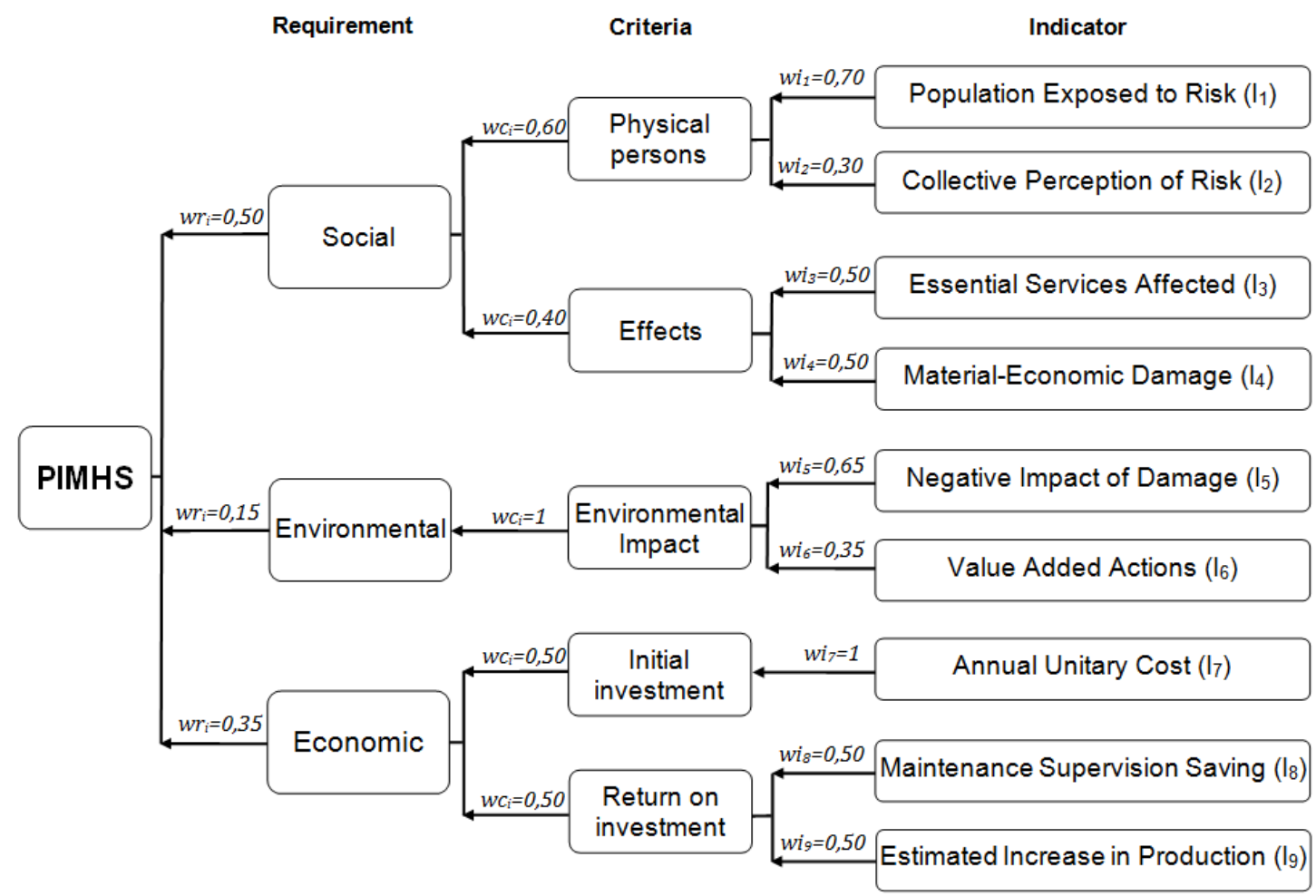


Figure 5. Annual Unitary Cost Value Function

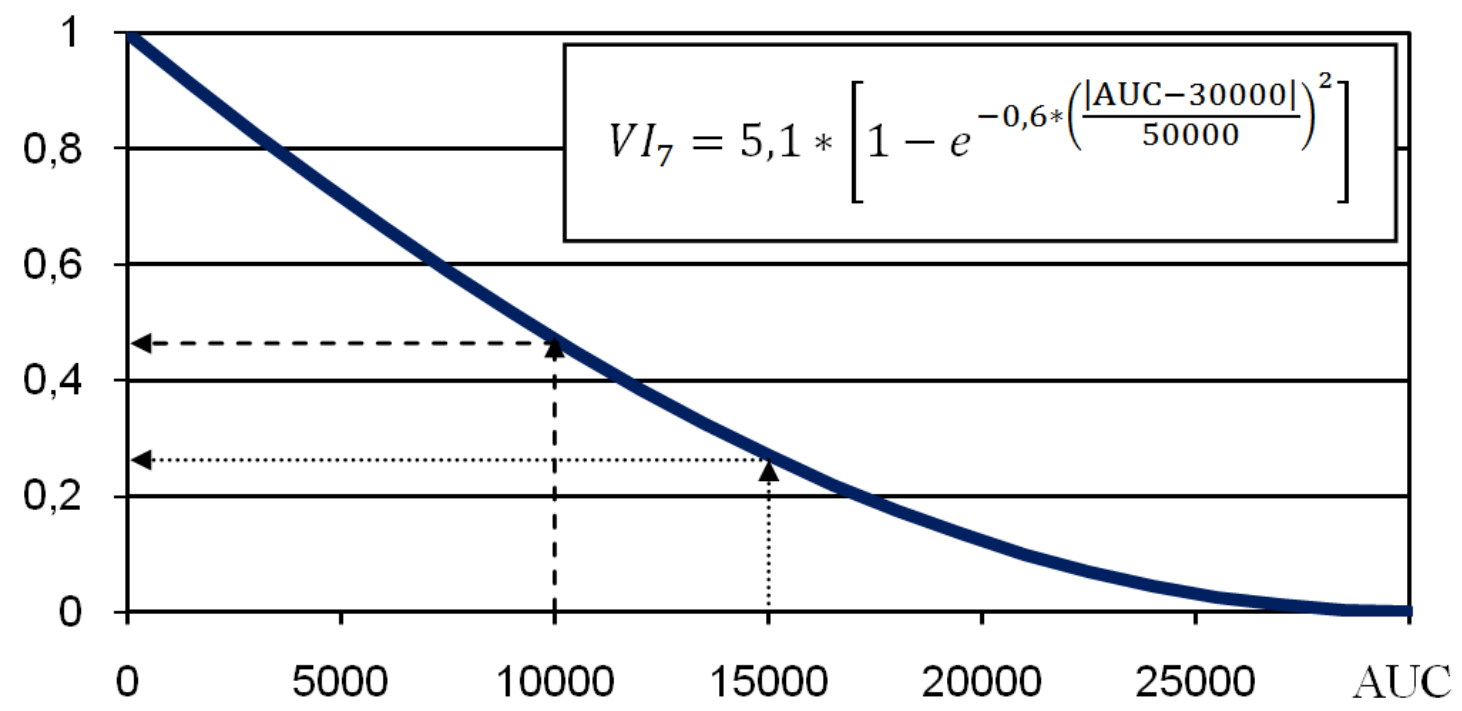

